Article

\title{
Assessment of Fire Effects on Surface Runoff Erosion Susceptibility: The Case of the Summer 2021 Forest Fires in Greece
}

\author{
Niki Evelpidou*(D), Maria Tzouxanioti (D), Theodore Gavalas, Evangelos Spyrou, Giannis Saitis (D), \\ Alexandros Petropoulos (D) and Anna Karkani (D)
}

Faculty of Geology and Geoenvironment, National and Kapodistrian University of Athens, 15774 Athens, Greece; mtzouxanioti@geol.uoa.gr (M.T.); tedgavgeo@geol.uoa.gr (T.G.); evspyrou@geol.uoa.gr (E.S.); saitij@geol.uoa.gr (G.S.); alexpetrop@geol.uoa.gr (A.P.); ekarkani@geol.uoa.gr (A.K.)

* Correspondence: evelpidou@geol.uoa.gr

Citation: Evelpidou, N.; Tzouxanioti, M.; Gavalas, T.; Spyrou, E.; Saitis, G.; Petropoulos, A.; Karkani, A. Assessment of Fire Effects on Surface Runoff Erosion Susceptibility: The Case of the Summer 2021 Forest Fires in Greece. Land 2022, 11, 21. https:// doi.org/10.3390/land11010021

Academic Editor: Artemi Cerdà

Received: 21 November 2021

Accepted: 21 December 2021

Published: 23 December 2021

Publisher's Note: MDPI stays neutral with regard to jurisdictional claims in published maps and institutional affiliations.

Copyright: (C) 2021 by the authors. Licensee MDPI, Basel, Switzerland. This article is an open access article distributed under the terms and conditions of the Creative Commons Attribution (CC BY) license (https:// creativecommons.org/licenses/by/ $4.0 /)$.

\begin{abstract}
The wildfires of summer 2021 in Greece were among the most severe forest fire events that have occurred in the country over the past decade. The conflagration period lasted for 20 days (i.e., from 27 July to 16 August 2021) and resulted in the devastation of an area of more than $3600 \mathrm{Km}^{2}$. Forest fire events of similar severity also struck other Mediterranean countries during this period. Apart from their direct impacts, forest fires also render an area more susceptible to runoff erosion by massively removing its vegetation, among other factors. It is clear that immediately after a forest fire, most areas are much more susceptible to erosion. In this paper, we evaluate the erosion hazard of Attica, Northern Euboea, and the Peloponnese that were devastated by forest fires during the summer of 2021 in Greece, in comparison with their geological and geomorphological structures, as well as land cover and management. Given that a very significant part of these areas were burnt during the major conflagrations of this summer, erosion risk, as well as flood risk, are expected to be very high, especially for the coming autumn and winter. For the evaluation of erosion risk, the burnt areas were mapped, and the final erosion-risk maps were constructed through GIS software. The final maps suggest that most of the burnt areas are highly susceptible to future surface runoff erosion events.
\end{abstract}

Keywords: surface runoff erosion; forest fire; vegetation; runoff; vulnerability; hazard

\section{Introduction}

The wildfires of summer 2021 in Greece were among the most severe forest fire events that have occurred in the country over the past decade. The conflagration period lasted for 20 days (i.e., from 27 July to 16 August 2021) and resulted in the devastation of an area of more than $3600 \mathrm{Km}^{2}$ [1].

Erosion refers to the removal of soil and rock particles (sediments) and their transportation away from their initial source [2-4]. In most cases, particles are mainly removed from their initial position via water.

Surface runoff erosion-risk maps have been developed for certain areas. The most common mapping methods include either mathematical models [5-8], or in situ observations and bibliographical research [6-10]. In the first method, erosion risk is evaluated and determined based on certain criteria posed by researchers. Therefore, in many cases, the results are subjective. In the second method, the main drawback is the fact that it is usually non-functional when it comes to areas at a regional scale; many errors might arise which would not be of high significance at a small scale, and the necessary field measurements might be very challenging [6] or very rough [8]. Field studies have been improved during the last decades, due to the development of remote sensing techniques [11-13]. Among the most important advances in field measurements and observations are the LiDAR [14-18] and unmanned aerial vehicles (UAVs or drones) $[19,20]$. 
Several models have also been developed over the last decades regarding runoff erosion hazard. For instance, until recently, one of the most common equations used when assessing runoff erosion hazard was the universal soil loss equation (USLE) [21]. Even though there are many other similar models for soil erosion, this equation was very commonly used, in view of the small number of required data. This is in contrary to most models, which require a large number of data that are often challenging to obtain, thus rendering the USLE a relatively simple means of estimating the soil erosion hazard. This model can also be used for areas of several scales [6,22]. According to the USLE, which is an empirical equation, the mean annual soil loss is found through a simple multiplication of five factors, i.e., rainfall erosivity, soil/rock erodibility, slope inclination, slope length and cover management [21]. A newer variation of the USLE is the Revised Universal Soil Loss Equation (RUSLE) [23]. This too is an empirical model, and is based on the USLE equation. It also includes other parameters that were not included in the original equation. This was mainly due to the fact that some data were difficult or impossible to obtain when the USLE was developed [23]. This model is especially useful when it comes to tropical climates [24]. The parameters that are included in the model are rainfall erosivity, soil/rock erodibility, slope inclination, slope length, land cover and management and support practices regarding soil loss [23]. These practices include, for instance, actions that are in place to reduce soil loss, and concern the slope gradient, the flow pattern, direction, etc. [25]. Another model commonly used in Europe is the Pan-European Soil Erosion Risk Assessment (PESERA) $[8,26,27]$. It is mainly used for large or medium-scale areas [8]. This model takes into account parameters such as topography, soil features, and the climate.

Some methodologies of artificial intelligence, especially fuzzy set theory, have also been previously applied to erosion issues [28-30]. Erosional hazard problems have been manipulated by the use of uncertainty factors and Boolean logic rules, or mathematically based erosion-risk self-organizing maps [31-34]. Artificial neural networks (ANN) have also been employed for landslide-susceptibility mapping [35,36] and soil erosion studies [37-39].

Surface runoff erosion is affected by many parameters. Initially, the climate plays a very important role, as runoff is created or enhanced after rainfall. The main climatic parameters include rainfall intensity and duration, precipitation type (rain, hail or snow) and raindrop size [34]. Furthermore, the characteristics of the corresponding drainage basin and networks are of paramount importance when it comes to surface runoff erosion, the most important parameter being the morphological slope gradient. Besides the physiographical and geomorphological characteristics of an area, its susceptibility to runoff erosion is also a function of the geological and/or pedological conditions. A rock's resistance to erosion is a determining factor regarding erosion. For instance, sandstones and mudstones are less resistant, and therefore more easily eroded than granites and gneisses. The permeability of soils are also affected by grain size and texture, with soil humidity also being very significant. An already wet soil can house a smaller amount of the precipitating water than a dry one. Additionally, its silt and clay percentage can alter its cohesion, which is larger in the case of a soil containing high amounts of mud, as opposed to sand. Soil roughness is also of primary importance [40-44]. Water flow is intercepted when the soil surface is rough (hence a reduction in its erodibility) [45,46]. Additionally, holes and openings are created where water can stagnate, thus facilitating infiltration [40,47-49]. Finally, land cover is a very important factor affecting an area's susceptibility to surface runoff erosion, mainly when it comes to soils [8]. Vegetation is one of the most important parameters of protection against erosion of any type. Plants intercept the falling raindrops, thus reducing their velocity and their erodibility. Furthermore, a portion of the rain does not fall on the soil, but instead remains on the plants' leaves until evaporation. Furthermore, the roots absorb part of the fallen water, thus reducing the amount of infiltrated water. They also disintegrate the soil, opening holes that allow even more water to infiltrate. In this way, more water can infiltrate the soil, and less water will run superficially. Finally, biomass offers extra protection against soil particle removal [2]. Of course, the type of vegetation also affects the extent of soil protection. A forest, for instance, offers much more protection 
against erosion than a bush-covered area. The tree type also influences soil erosion [50]. Wide-leaved trees (such as walnut trees, fig trees and sycamores) infiltrate a greater amount of water than needle-leaved ones (e.g., pines) or thin-leaved ones (e.g., kermes).

In addition, land cover refers to both land use and land management. Land cover primarily regards vegetation characteristics. For example, the denser the vegetation cover, the higher the protection it offers against soil erosion. This means that forest areas are less vulnerable to erosion than shrubs. Land management refers to the applied land techniques. An area covered by forests is much more protected than an agricultural area, which is, in turn, less susceptible to erosion than an urban area. Even in the case of agricultural areas, there are many subcases. A cultivated area is more easily eroded than a non-cultivated agricultural area [51]. Furthermore, different agricultural practices bear a different impact on the soil's vulnerability to runoff erosion [52]. For example, tilling techniques generally lead to an increase in the sand's proportion in the soil, as well as a decrease in the soil's permeability [53,54]. In addition, overgrazing reduces an area's protection against soil erosion. On the contrary, the creation of artificial terraces is very helpful in reducing the negative effects of flowing water. Increasing the soil's roughness can also be protective. Finally, another human intervention that severely affects an area's susceptibility to runoff erosion are extensive fires, although they may also occasionally be owed to natural causes. It has been proven that almost any region is far more vulnerable to erosion immediately after a fire. A conflagration results in the reduction of both vegetation and biomass protective cover. This means that all types of protection against erosion are diminished. Therefore, all areas are far more susceptible to erosion, as well as floods, after a conflagration.

Generally speaking, runoff erosion is increased immediately after a fire [55-61]. However, certain researchers [62-64] have studied erosion risk in certain areas after fires, and did not spot any significant increase in erosion risk in comparison with the erosion risk of periods where no fires had occurred. In most cases, in areas affected by forest fires, runoff erosion, as well as flooding problems arise. They usually result in many infrastructure damages, as well as fatalities, not to mention ecological and environmental issues [65]. Additionally, erosion results in the denudation of cultivable areas, thus creating agricultural problems, as well as problems regarding both the quality and quantity of potable water $[66,67]$. Soil is the component that enables plants to grow and, therefore, allows agricultural activities to take place. Consequently, its removal hinders said activities. Moreover, through the removal of soil, several nutrients (either naturally present in soils or artificially through fertilizers, pesticides etc.) are removed as well. They follow the course of water, thus usually ending up in water bodies (e.g., lakes), or in the sea. One of the most typical consequences of this regime is eutrophication.

Fire affects an area's susceptibility to erosion by impacting the soil properties, among other factors $[68,69]$. For example, physical and other properties can be altered due to the heat caused by the fire, including the soil's content in organic material, its porosity and permeability, and its shear strength, as well as its infiltration capacity [64,70-77]. Another direct effect of fires is the removal of vegetation [78], which acts as a protective cover that prevents the soil particles from being removed under normal conditions $[75,79,80]$. Fire also reduces soil roughness [43]. Of course, the intensity of the fire itself plays a very important role, as a more intense fire and/or a fire that has incinerated a large area, increases erosion, as well as flood risk, to a much greater effect than a milder one [74,81].

In this paper, we examine the vulnerability to surface runoff erosion of several Greek regions that were recently affected by forest fires, and try to identify areas that are more likely to suffer from future erosion events. The areas studied in this research do not share the same geological and geomorphological characteristics, meaning that the effects of forest fires will be examined in connection with the overall structure. The selected areas have suffered by fire events during the summer of 2021, namely Attica, Euboea, and the Peloponnese. The goal of this research is to assess their vulnerability to erosion immediately after the devastating conflagrations, through the development of corresponding maps. For this purpose, the burnt areas were mapped through GIS, and they were combined to other 
data of the study areas, such as geology, geomorphology, land cover, etc. The final erosionrisk maps illustrate which parts of the burnt areas are more prone to imminent extreme weather phenomena regarding surface runoff erosion.

\section{Study Areas}

Three Greek areas were studied: Attica, Northern Euboea, and the Peloponnese (Figure 1). Attica is one of the regional units (formerly prefectures) in the geographical department of Central Greece, covering an area of $3023 \mathrm{Km}^{2}$. Euboea is Greece's second largest island (after Crete) and one of Central Greece's regional units (formerly prefectures), covering an area of $3658 \mathrm{Km}^{2}$. The Peloponnese is one of Greece's geographical departments, covering an area of $21650 \mathrm{Km}^{2}$. All areas are characterized by Mediterranean climate, i.e., by hot and dry summers and mild winters. Rainfalls mainly occur during the wet season, during autumn and winter. According to the climatic data provided by the Hellenic National Meteorological Service [82], in Attica, the mean annual precipitation reaches 402 $\mathrm{mm}$, as measured from the stations of Elliniko, Elefsina, Tatoi and Nea Philadelphia. The minimum precipitation is during the summer months $(8 \mathrm{~mm}$ in June, $7 \mathrm{~mm}$ in July and $6 \mathrm{~mm}$ in August), whereas maximum precipitation occurs during November (61 mm), December $(69 \mathrm{~mm})$ and January $(54 \mathrm{~mm})$. In Euboea, mean annual precipitation reaches 506 $\mathrm{mm}$, according to measurements from adjacent meteorological stations (Skyros, Tanagra, Aliartos and Lamia). Maximum and minimum precipitation height occurs during the same months as in Attica (maximum precipitation reaches $66 \mathrm{~mm}$ in November, 82 in December and 70 in January, whereas minimum precipitation reaches $13 \mathrm{~mm}$ in June, 10 in July and 13 in August). In the Peloponnese, measurements from the stations of Tripolis, Kalamata and Velo indicate that the mean annual precipitation reaches $665 \mathrm{~mm}$, with minimum values during the summer ( $8 \mathrm{~mm}$ in June, 6 in July and 11 in August) and maximum values during November (108 $\mathrm{mm})$, December $(115 \mathrm{~mm})$ and January $(94 \mathrm{~mm})$. Rapid and intense weather phenomena, such as thunderstorms, and strong winds are not uncommon in the study areas.

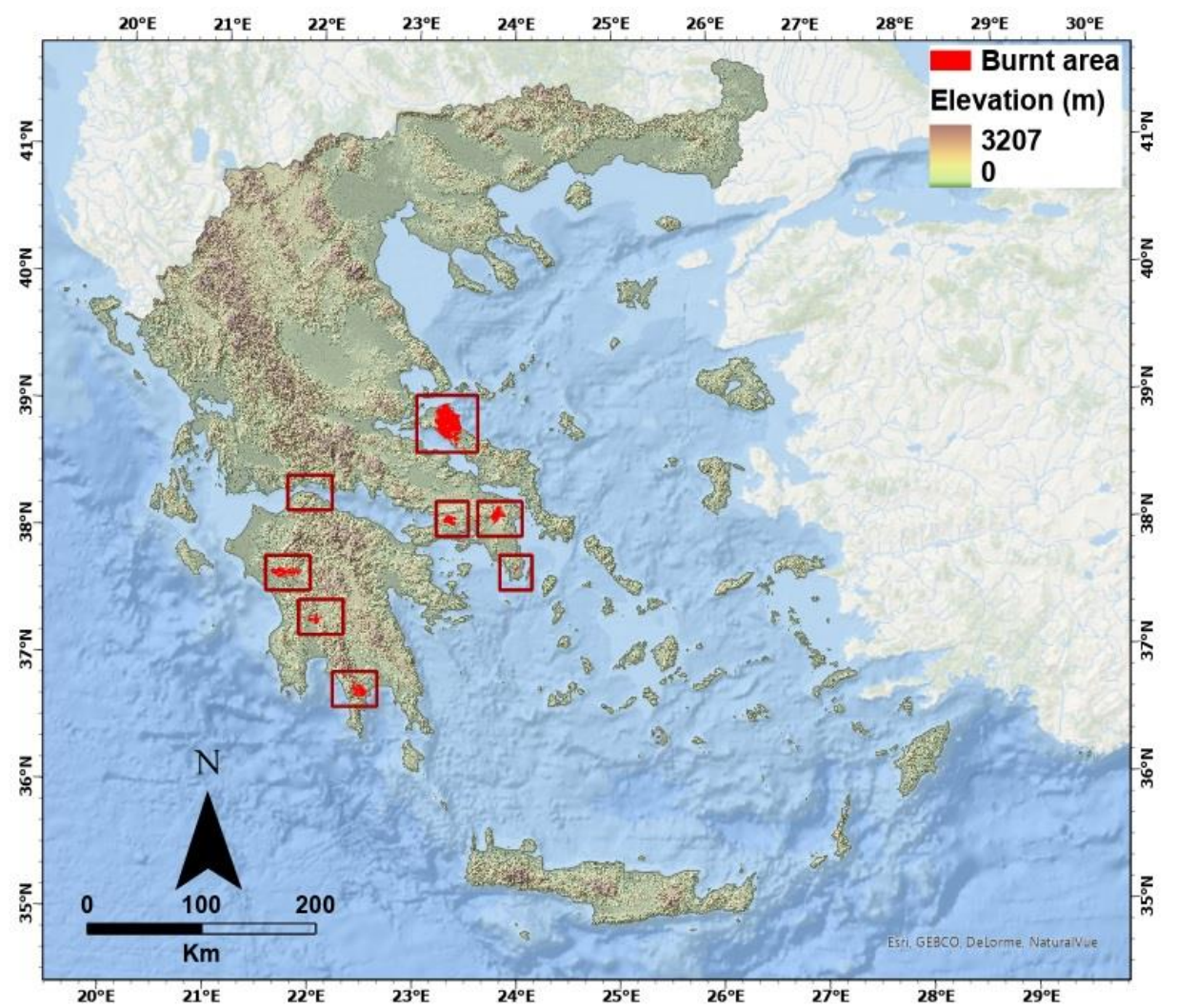

Figure 1. Location of the studied areas. The areas burnt during the 2021 fires are marked with red color. 
The increased vulnerability of these areas to forest fires during this period is totally justified. Initially, the largest part of these areas was, as will be shown, covered by softleaved vegetation (forests, cultivations, etc.) that renders them highly vulnerable to forest fires. Moreover, several severe heat waves have previously struck the Balkan region. Temperatures reached and even exceeded $40{ }^{\circ} \mathrm{C}$ for several successive days. As a result, the air temperature was very high during the summer of 2021, whereas soil moisture was very low. These conditions, in connection to the lack of precipitation during this period, rendered the Balkan Peninsula, and Greece in particular, extremely vulnerable to forest fires [1].

\subsection{Attica}

The areas burnt during the devastating fires of August 2021 include three individual areas: the broader regions of Varympompi, Villia and Sounion national forest (Lavrion area) (Figure 2). In Varympompi area, the burnt land is mainly composed of lacustrine, fluvial and terrestrial Neogene sediments found in its northwestern part, and, to a lesser extent, limestones (locally dolomites), covering its southeastern part. A small part is covered by metamorphic rocks (clastic and, secondarily, marbles), mainly located in the far northeastern part [1]. With regard to land cover, the largest part of the burnt land was covered by forest vegetation (mainly broad-leaved, coniferous and mixed forests) and transitional zones between forest and shrub vegetation, whereas a smaller part was covered by cultivable and/or cultivated areas and urban fabric [83]. The burnt area was $85 \mathrm{Km}^{2}$. Settlements within the burnt areas include Varympompi, Ippokrateios Politeia, Tatoi, Afidnes, Pefkofyton, Aghios Stephanos and Kryonerion. The urban fabric in the area, especially in the settlements of Ippokrateios Politeia, Tatoi and Afidnes, is well-developed.

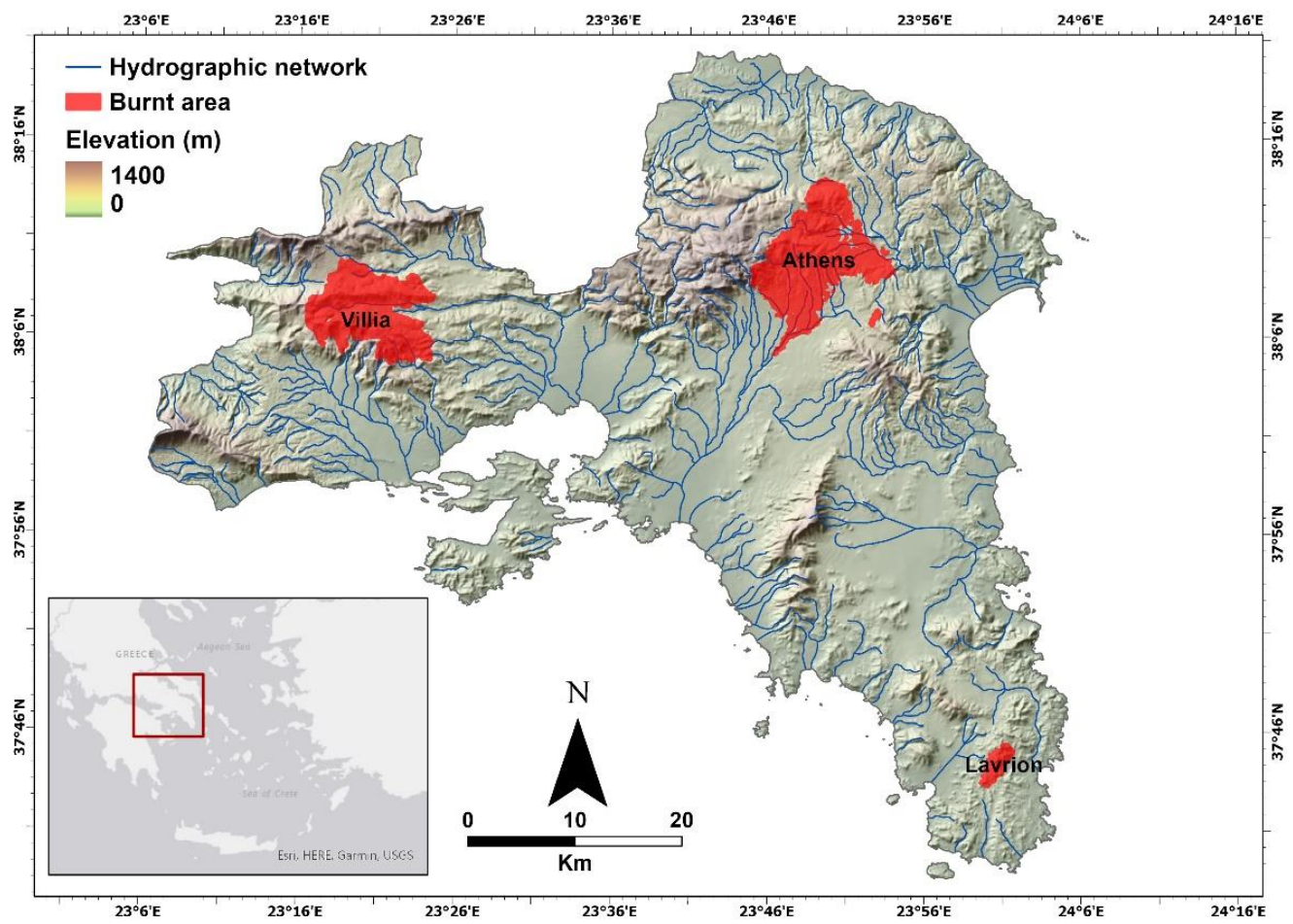

Figure 2. The fire affected areas host a well-developed drainage system, part of which are draining urban areas. Two main hydrographic systems exist in the wider area of Varimpompi fire affected area, Oinoi river, which flows towards Marathon, and Kifissos river, which flows towards western suburbs of Attica.

In Sounion National Forest (Lavrion area), the burnt area was mainly covered by schists and, to a lesser extent, marbles. As its name states, its largest part was covered by forests of several types (e.g., sclerophyllous, coniferous) and shrubs, although there 
were also cultivated areas. More specifically, five main vegetation units were found, each covering an almost equal area to the others. These units included cultivations, coniferous forests, sclerophyllous forests, mixed forests and shrubs. The total burnt area in Lavrion was $5.5 \mathrm{Km}^{2}$ [1]. As far as Villia area is concerned, almost all of the burnt lands were covered by natural vegetation, i.e., forests, mainly sclerophyllous and coniferous, as well as shrubs and grasslands. The total burnt area in Villia reached $66 \mathrm{Km}^{2}$.

According to the aforementioned, land cover did facilitate the spreading of the forest fires, in association with the heat waves that had previously affected Greece. Regarding the fire-affected areas of Attica Prefecture, they host well-developed drainage systems, partly draining urban areas. There are two main hydrographic systems in the wider area of Varympompi area (Figure 2). The main drainage networks are the Oinois river, flowing towards Marathon, and Kifissos river, flowing towards the western suburbs of Attica. In the fire-affected area in Villia, a drainage system crosses it for about $10 \mathrm{Km}$ in an East-West direction, and finally ends up in the area of Elefsina. There are also smaller catchments passing through the fire-affected area, flowing towards Nea Peramos (Figure 3).

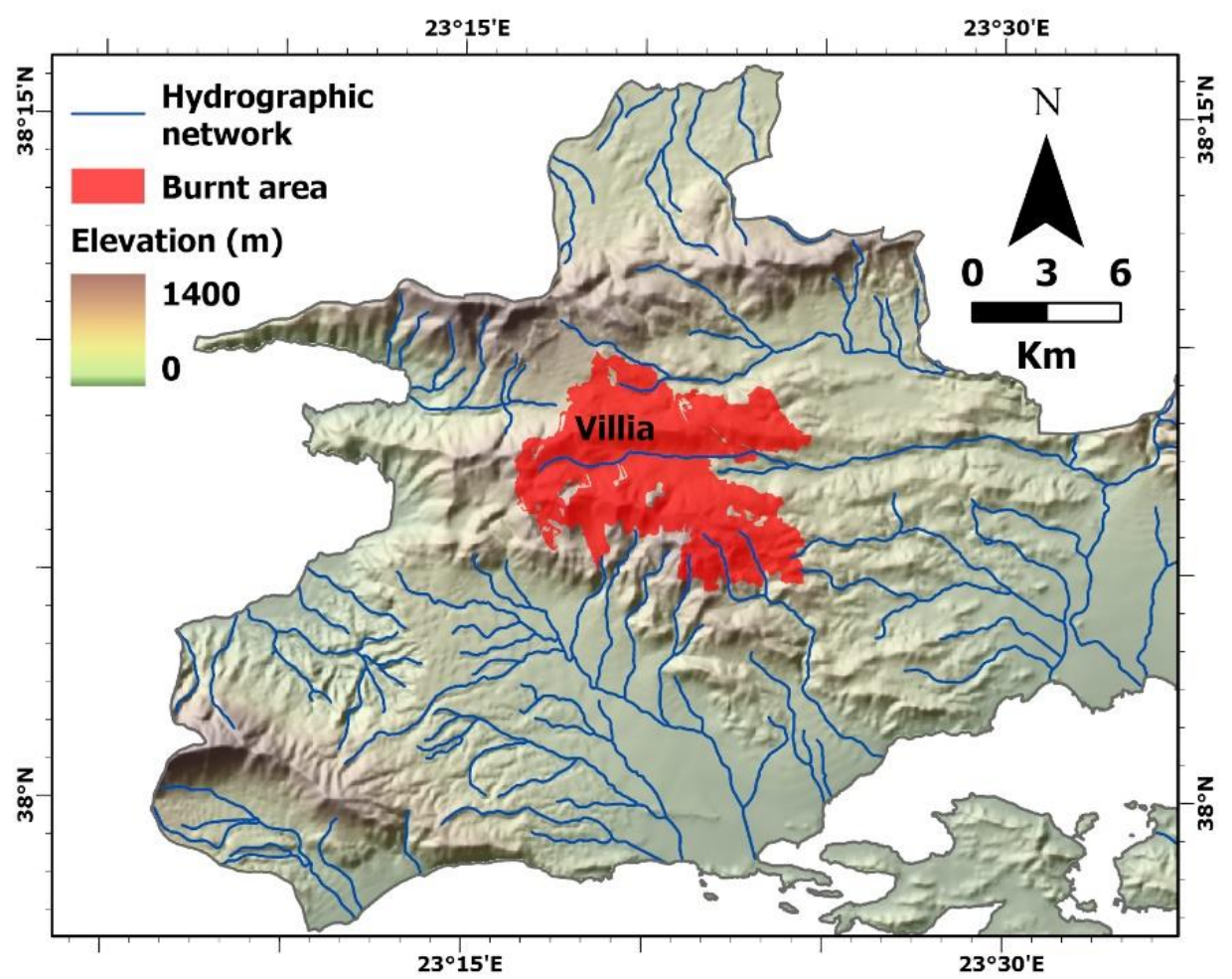

Figure 3. The map depicts the total burnt area of Villia, where a drainage system crosses the affected area in an East-West direction.

In Attica, the areas burnt during the devastating fires of August 2021 include the broader regions of Varympompi, Villia and Sounion national forest, with the total burnt area reaching approximately $155 \mathrm{Km}^{2}$ [1].

The morphological slope distribution of Attica is shown in Figure 4. Large slopes cover more than half of the fire-affected areas. More specifically, 53\% of the area's slopes have an inclination of more than $10^{\circ}, 1 \%$ of which exceeds the inclination of $30^{\circ}$. Additionally, $29 \%$ of the total area is of medium slope, with inclinations fluctuating between $10^{\circ}$ and $4^{\circ}$, whereas $18 \%$ is characterized by an inclination of less than $4^{\circ}$. 


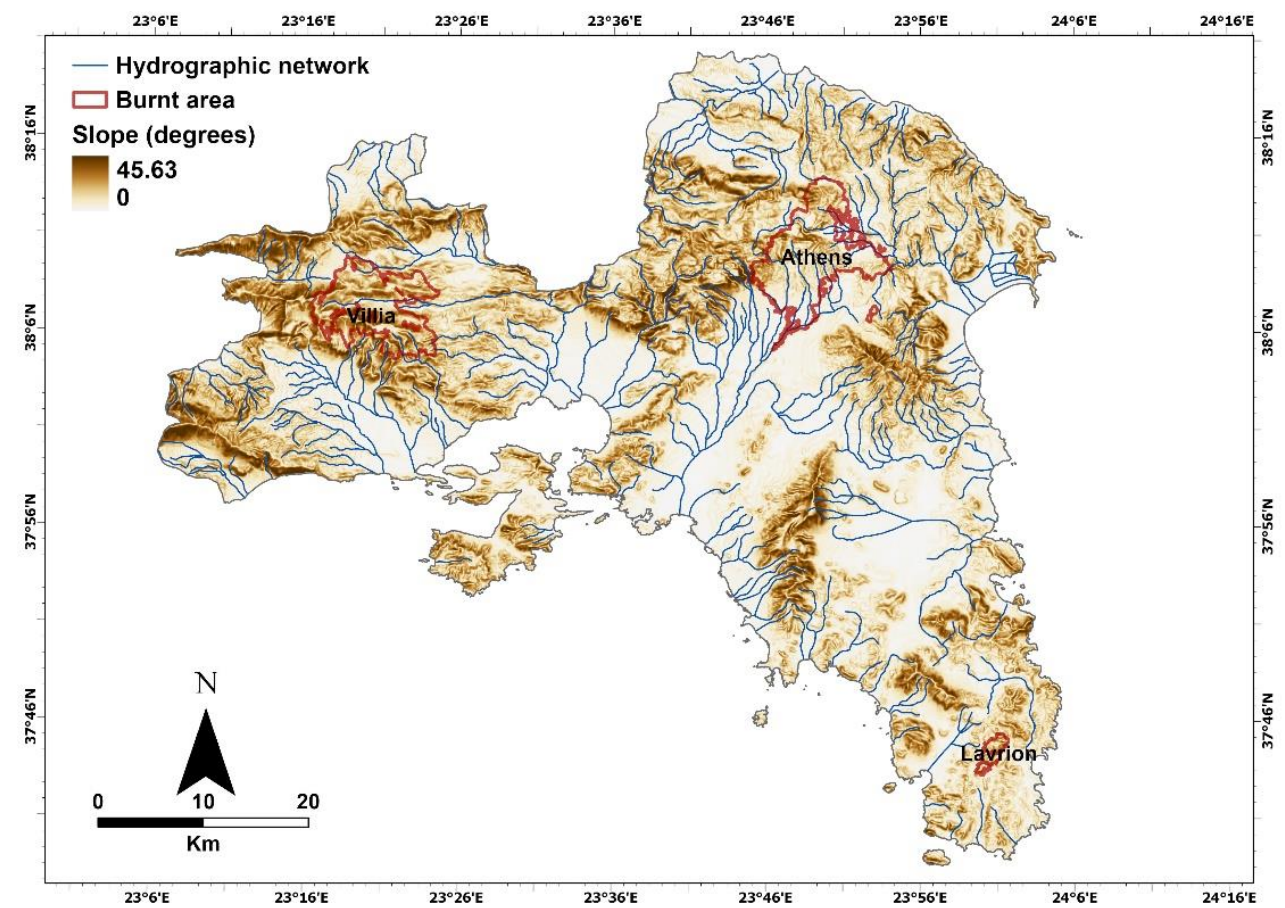

Figure 4. Morphological slopes of the fire-affected areas in Attica.

\subsection{Northern Euboea}

In Euboea island, a significant area in its northern part was burnt, specifically the area of Pefki-Aghia Anna-Rovies, i.e., an area of more than $505 \mathrm{Km}^{2}$ [1] (Figure 5). As far as geology is concerned, the largest part of the burnt area is composed of lacustrine, terrestrial and fluvio-lacustrine sediments of Neogene age, with ultramafic rocks (peridotites and amphibolites) covering small, individual parts. Carbonates and mica schists cover only a very small part. According to CORINE [83], almost all the studied area was covered by coniferous and broad-leaved forests, whereas only a small part included cultivable land, meaning that any fire of a small scale could easily obtain the severity of the August 2021 fires. Among the most significant settlements within the conflagrated area are Aghia Anna, Rovies, Lymni, Pappades, Kerasia, Vassilika and Pefki. The rural fabric is not welldeveloped, as most of the area is woodland and all the aforementioned settlements are small villages.

The fire-affected area is characterized by abrupt slopes, downcutting erosion and a dense drainage system. Most of the drainage basins are small with small hydrographic networks, yet there are few large drainage basins covering a significant part of the fireaffected area, ending up at Gouves, Rovies, Neochori and Krya Vrysi.

The morphological slope distribution of Euboea is shown in Figure 6. Large slopes cover more than half of the fire-affected areas. Moreover, $63.1 \%$ of the slopes have an inclination between $10^{\circ}$ and $30^{\circ}$ (medium slopes), and $14.5 \%$ of the total area is characterized by low slope, with inclinations fluctuating between $10^{\circ}$ and $4^{\circ}$, whereas $5.8 \%$ is characterized by an inclination of less than $4^{\circ}$ (very low slopes). The remaining $16.6 \%$ of the area's slopes have an inclination of more than $30^{\circ}$ (high slopes). 


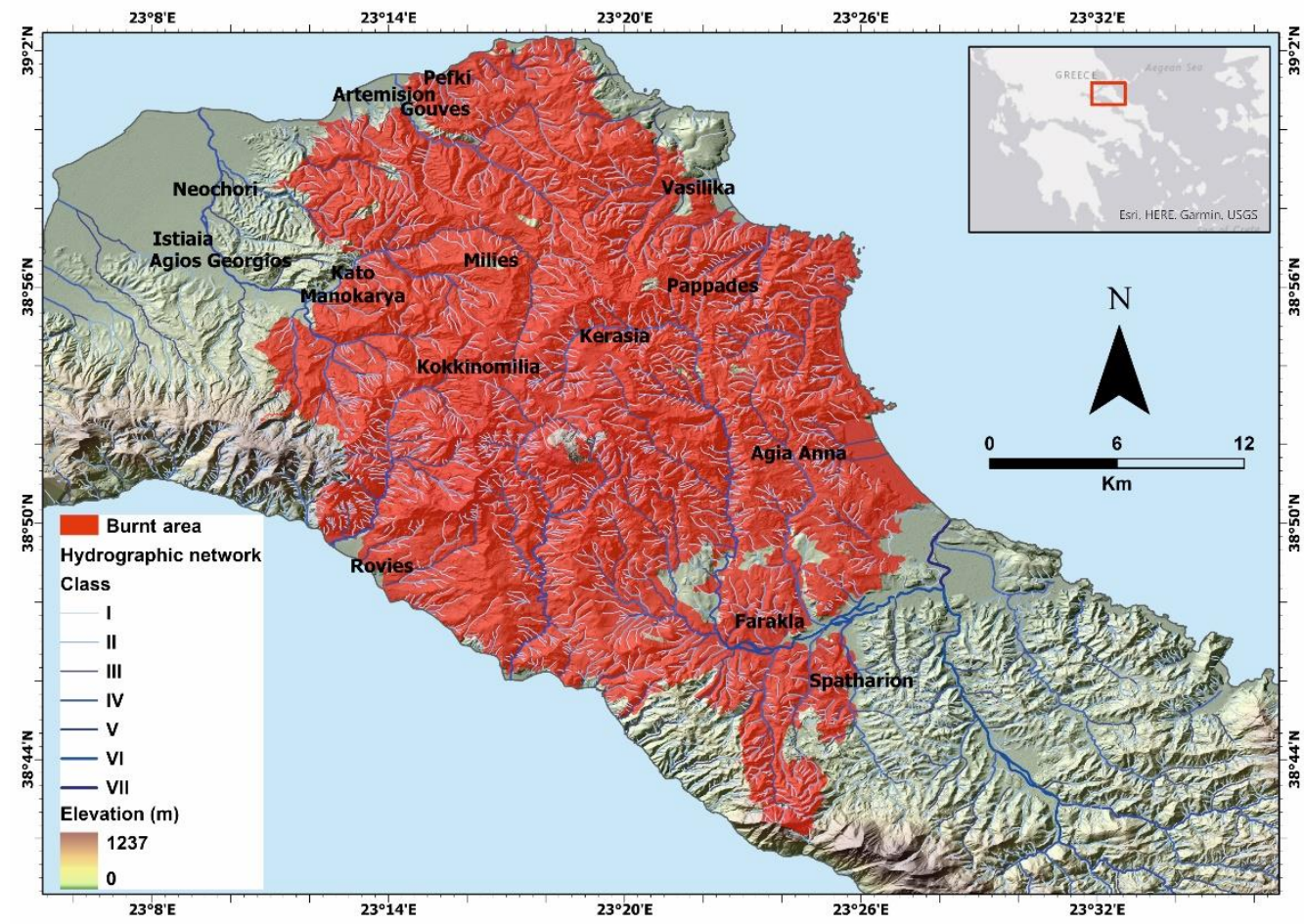

Figure 5. The fire affected area in Euboea along with the drainage network.

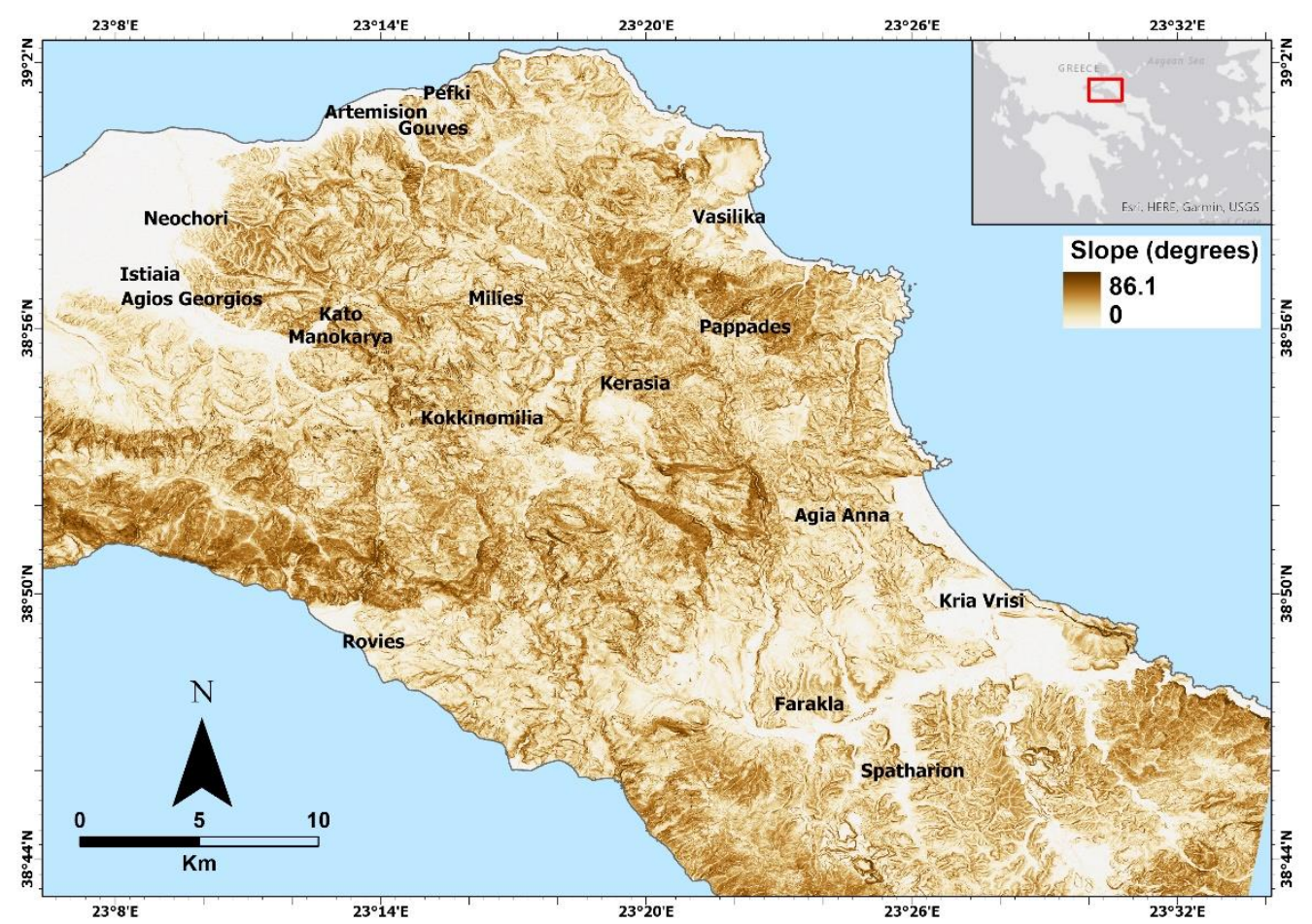

Figure 6. Morphological slopes of the fire-affected area in Northern Euboea.

\subsection{The Peloponnese}

In the Peloponnese, four main individual fire outbreaks took place, namely in Aigialeia, Ancient Olympia, Diavolitsi and East Mani. The burnt area reached approximately $291 \mathrm{Km}^{2}$ (Figure 7) [1]. 

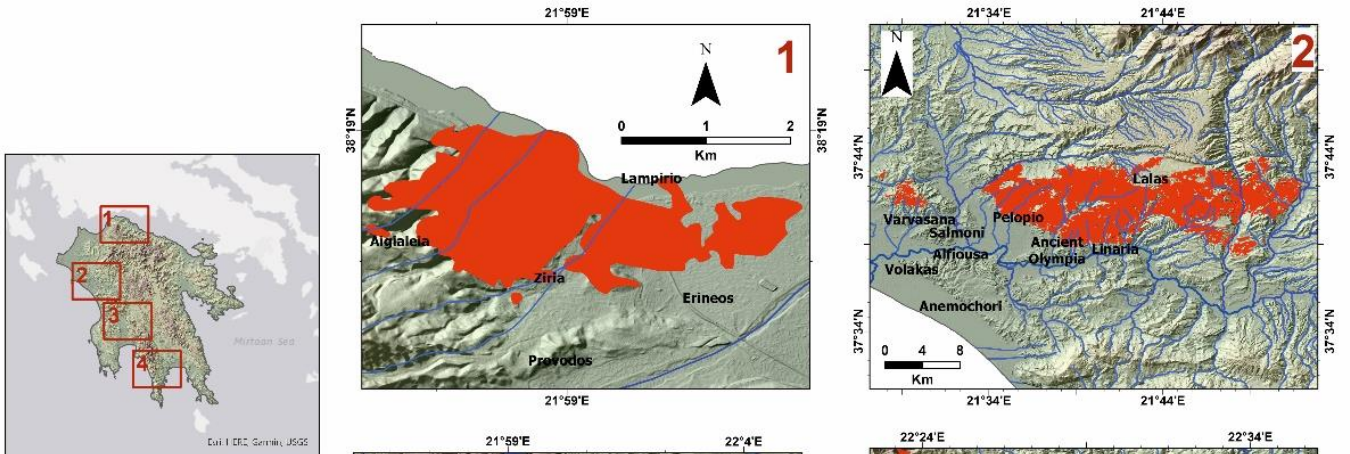

Burnt area

Hydrographic network

Class

- I

- II

Elevation (m)

3207

0
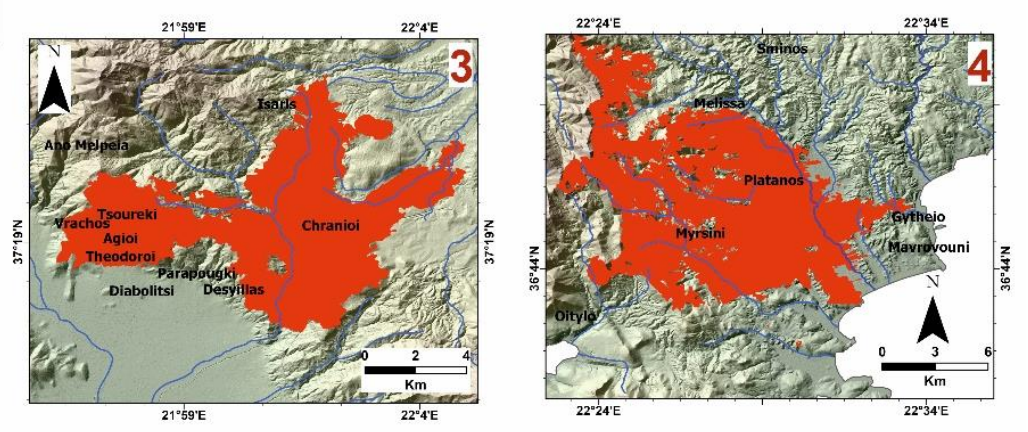

Figure 7. The fire-affected areas in the Peloponnese.

In the Aigialeia region, post-alpine sediments are exclusively found, mainly marls of the Pliocene-Pleistocene age, sandy clays and Quaternary conglomerates [1]. Land cover in the burnt area includes coniferous and shrub vegetation and cultivations, their proportion being almost equal [83]. Artificial surfaces, primarily railways and motorways, mainly occupy the coastal part of the region. A total of $3 \mathrm{Km}^{2}$ were burnt, including the settlements of Lampirion, Ziria, Ano Ziria and Kamari [84].

In Ancient Olympia, post-alpine sediments are also exclusively found, specifically of Pliocene to Quaternary age, and of several phases [1]. Land cover mainly includes cultivations, and only forest to a small extent. A total area of $135 \mathrm{Km}^{2}$ was devastated during the wildfires, the affected settlements including Lampeti, Lalas and Ancient Olympia [1].

In Diavolitsi area, almost $47 \mathrm{Km}^{2}$ were burnt. The region was half occupied by cultivations and half by forests. In Messinia (Diabolitsi) area, the burnt land is mainly covered by Radiolarites and pelagic limestones with intercalations of silex, marls and sandstones. A small part is covered by flysch and limestones. Finally, in Eastern Mani, almost $105 \mathrm{Km}^{2}$ were burnt, including the settlements Kastania, Melissa, Sidirokastron, Myrsini and Gytheion. This area too was occupied by forests and cultivations, with the former covering a larger part than the latter. In all cases, the settlements are small, mainly rural villages with no significant urban fabric.

Land cover in these four areas favored the spreading of the devastating fires, as a significant part of them was covered by low vegetation (e.g., cultivations), even though forests covered a smaller part in comparison with the previous regions (Euboea and Attica). The fire-affected areas are characterized by high elevations (Figure 7) and steep morphological slopes (Figure 8). In the areas of Ancient Olympia and East Mani, a welldeveloped drainage system is observed, contrary to the area of Aigialeia, which is mainly flat. In all cases but Aigialeia, more than $80 \%$ of the burnt areas are characterized by slopes whose inclination exceeds $10^{\circ}$. More specifically, in Aigialeia, $22 \%$ of the slopes have an inclination of more than $30^{\circ}$, and $32 \%$ are between $10^{\circ}$ and $30^{\circ}$. The remaining $20 \%$ and $27 \%$ include slopes with an inclination of $4^{\circ}$ to $10^{\circ}$, and less than $4^{\circ}$, respectively. In Ancient Olympia, the slopes with an inclination of $10^{\circ}$ to $30^{\circ}$ reach $52 \%$, whereas those exceeding $30^{\circ}$ reach $28 \%$. Only $5 \%$ is characterized by an inclination of less than $4^{\circ}$. Similarly, in the Diavolitsi area, $62 \%$ and a $24 \%$ of the slopes have an inclination of $10^{\circ}$ to $30^{\circ}$, and more than $30^{\circ}$, respectively; the flat areas (less than $4^{\circ}$ in inclination) only cover $3 \%$ of the total area. Finally, in Mani, the areas with more than $30^{\circ}$, and between $10^{\circ}$ to $30^{\circ}$ slopes, are 
almost equal, covering $48 \%$ and $35 \%$ of the burnt areas, respectively. Ultimately, $11 \%$ of the area is characterized by slopes between $4^{\circ}$ and $10^{\circ}$.

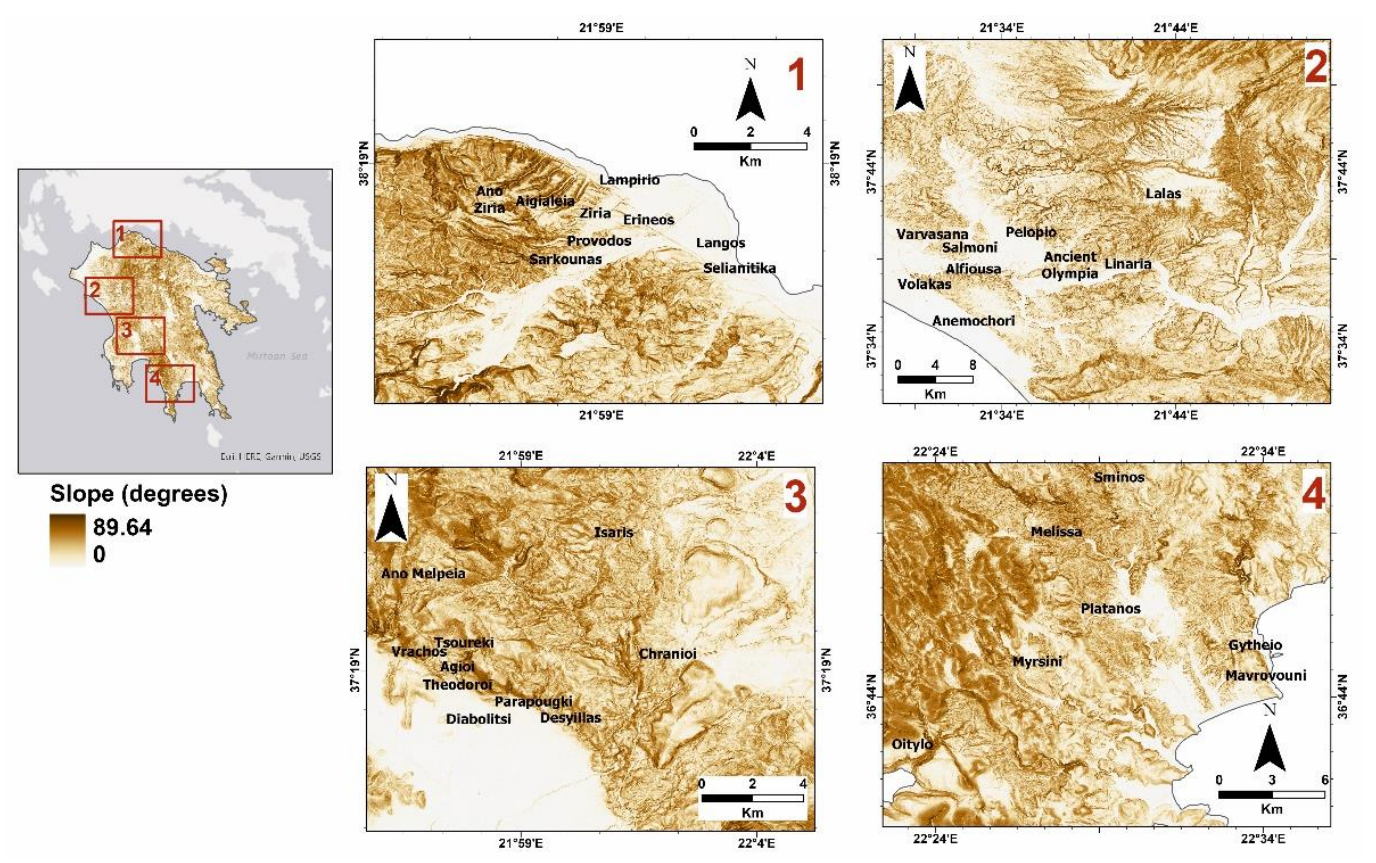

Figure 8. Morphological slopes of the fire-affected areas in Peloponnese.

\section{Materials and Methods}

For this research, the overall geological and geomorphological structures of the burnt areas were studied. The data used were derived from the bibliography, from several measurements through GIS programs (namely ArcGIS Pro and MapInfo Pro) and from field work conducted for the needs of previous research in the study areas. Additionally, a visit in each of the burnt areas was conducted immediately after the fires. Therefore, more field observations were made regarding the morphology of these areas after the fire in comparison with the previous morphology, as well as considering the direct effects of the fires, such as the destruction of vegetation.

All the collected data were imported into GIS. (ArcGIS Pro version 2.8.3 and MapInfo Pro version 12.5) and the erosion risk was evaluated using a Boolean logic-based model. The main parameters used in this stage were land uses, slope, drainage density and lithology. These logical associations are expressed through a set of Boolean logic rules (Table S1). Boolean rules assign four values to lithology and slope parameters (high, medium, low, very low) and take into account high drainage density and land-use type values. The final estimation of erosion risk is categorized into six values (very high, high, medium, low, very low and deposition).

\section{Results and Discussion}

The surface runoff erosion hazard for Attica Prefecture is shown in Figure 9. The broader area of Vilia is not characterized by a high risk, despite the medium to high slope gradient, which would facilitate the removal of soil and rock material (i.e., accelerates erosion). Yet, the burnt areas were slightly more vulnerable to erosion than the surrounding area. The former was characterized by a low risk, whereas the latter by a very low risk. The same situation was observed in Varympompi. The morphological slopes were relatively high in the broader area, meaning that they already facilitated runoff erosion: they were generally uniform with less fluctuations. Yet, the burnt area was characterized by a low risk, and the surrounding area was generally of very low risk. The area of Sounion showed a similar regime. In this case too, the slopes were generally uniform and intermediate, 
compared with the other two regions. The erosion risk was low to medium for the burnt area, and very low for the rest of the region.
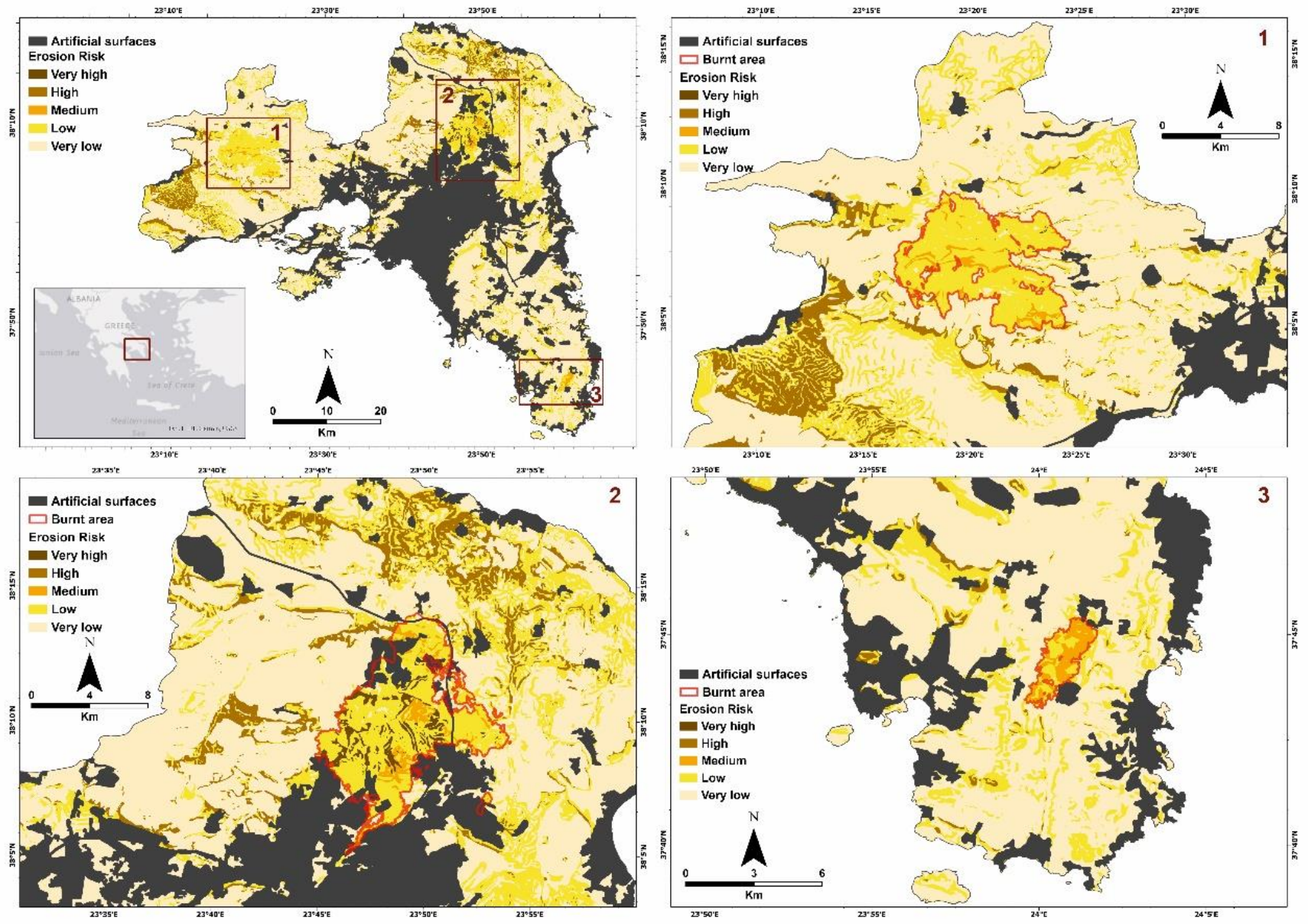

Figure 9. Results of erosion risk in the fire-affected area of Attica using a Boolean logic-based model. The map on the top right shows the erosion risk in the total investigated area, and the numbers correspond to the other three individual maps, where (1) is Attica, (2) is Villia and (3) is Lavrion.

The erosion risk map of Northern Euboea is shown in Figure 10. It is clear that the whole area is particularly prone to runoff erosion. This is due to the combination of its geological structure and the morphological slope distribution. Neogene sediments prevailed in the study area, which are very erodible. Additionally, the slope gradient was characterized by high to very high values. Yet, the burnt areas were more susceptible by one factor. More specifically, the burnt areas were generally characterized by a very high risk, which was high to medium in some individual parts; the non-burnt areas were of high to medium risk, as a total.

Figure 11 shows the erosion risk distribution for the fire-affected areas of the Peloponnese. In the area of Aigialeia, erosion risk is well-distributed; it ranges from very low to very high depending on the area. The part near the sea was of very low to non-existent risk. The rest of the area shows a similar regime to northern Euboea; the burnt area was of medium to very high risk, whereas the surrounding region was of low to medium risk. High risk only characterized a few individual parts. This regime was also facilitated by the slope, which ranges from very high in the inland part to very low in the coastal part. Regarding eastern Mani, the situation was similar; the burnt region was of low, and in certain areas, medium erosion risk, whereas the erosion risk was very low in the surrounding area. The morphological slope had an evident impact on the distribution of the high and low hazard areas, as the slopes generally decrease eastwards, as do the erosion hazards in general. In 
Diavolitsi, correspondingly, the burnt areas were characterized by a low to medium risk, whilst the surrounding areas were of low to very low risk. Finally, in ancient Olympia, the difference in the erosion risk was more intense, with the burnt areas showing high to very high erosion risk and the rest of the area low to non-existent risk.

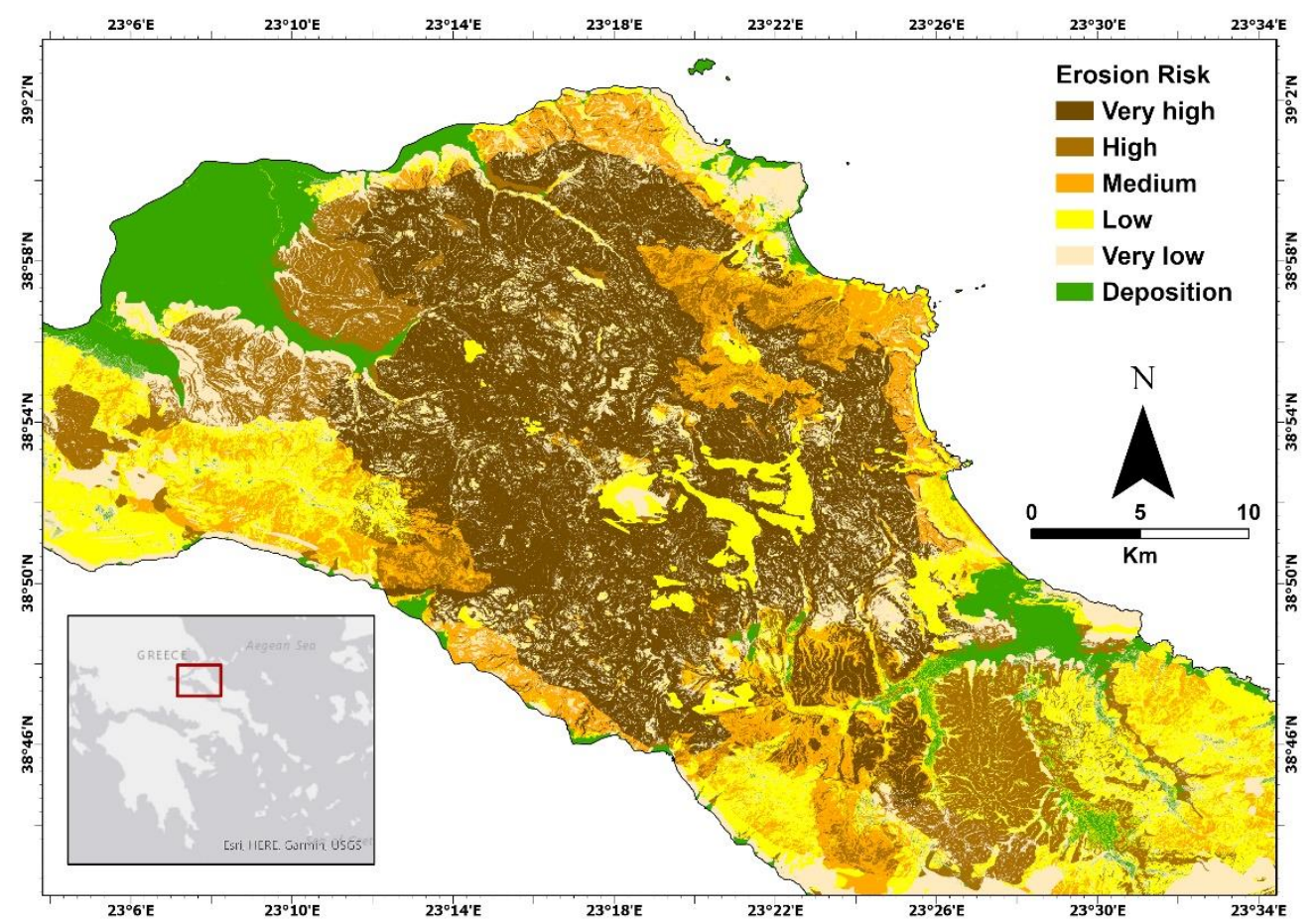

Figure 10. Results of erosion risk in the fire affected area of North Euboea using a Boolean logicbased model.
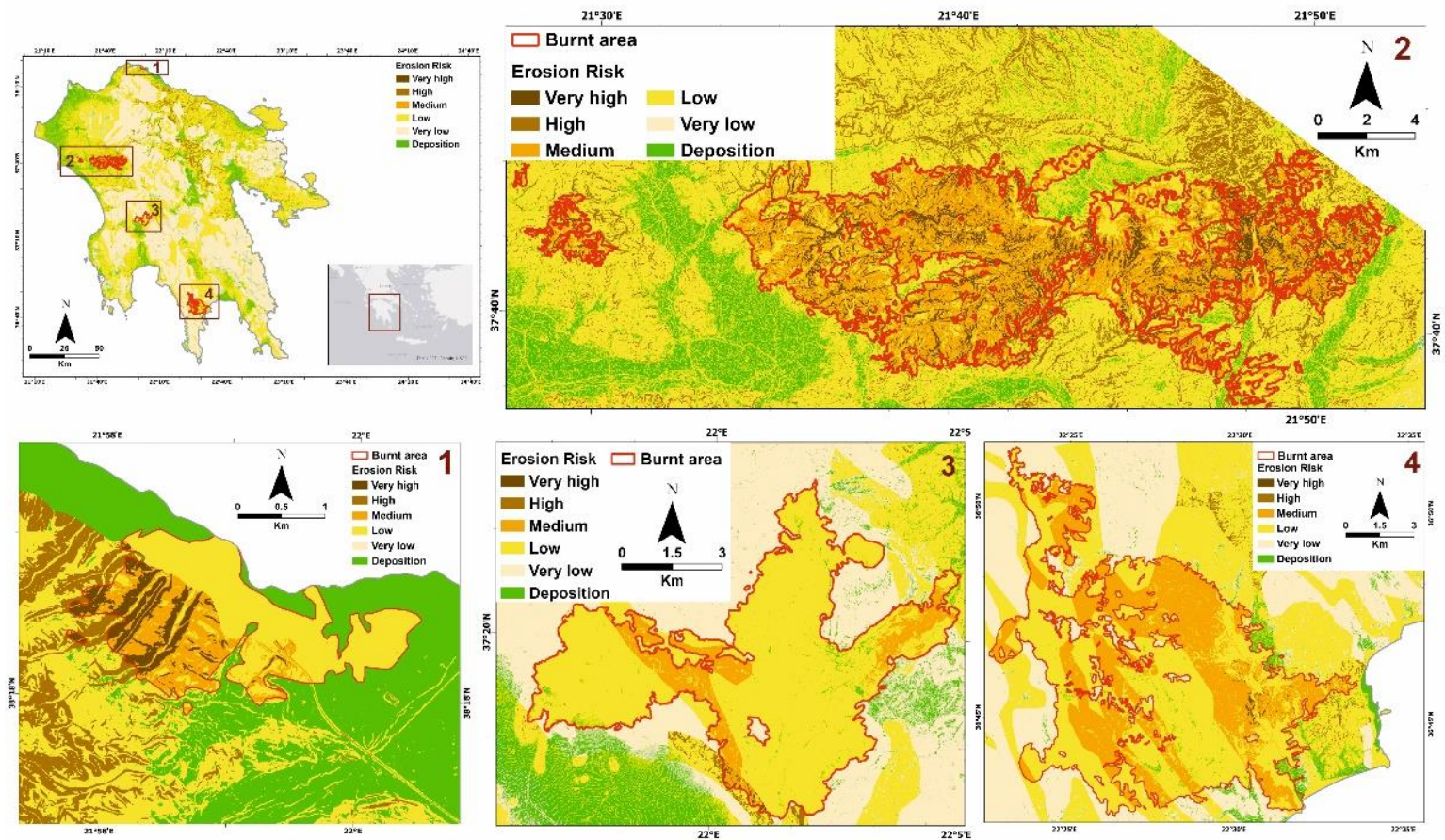

Figure 11. Results of erosion risk in the fire-affected area of the Peloponnese using a Boolean logicbased model. The map on the top right shows the location of the investigated areas the numbers corresponding to the other four individual maps, where (1) is Aigialeia, (2) is Ancient Olympia, (3) is Diavolitsi and (4) is Eastern Mani. 
Besides land degradation, other indirect impacts of soil erosion include increased flood risk, problems in the quality of potable water, disruptions in the ecosystems and others [85]. Runoff erosion poses a significant geological problem of Europe. Yet, the intensity of runoff erosion is not uniform all over the continent. In the Mediterranean, runoff erosion is very intense, as the dry period lasts for a significant amount of time and heavy rain and storm events are very common during the wet season, whereas in many parts, the slopes are steep and/or covered with erodible material $[6,86]$. On the contrary, the northern parts of Europe are much less susceptible to runoff erosion [6]. In most cases, runoff erosion is also facilitated by inappropriate cultivation methods, as well as other human interventions, such as deforestation and overgrazing, which are very common in Mediterranean countries [87-90].

According to CORINE [91], the evaluation of erosion risk in Greece, Italy, southern France, Spain and Portugal, and Southern France, showed that a part of Italy and northern Greece are of low risk, whereas the rest of Greece is characterized by moderate risk. The central part of Italy and almost all the Iberian Peninsula are characterized by moderate to high risk. Another research by RIVM [92], considering almost all Europe, has classified most parts of the Balkan peninsula, Italy, Spain, Turkey, northern Switzerland, Germany and western Ukraine as highly susceptible to surface runoff erosion, whereas northern France and eastern Ukraine and Belarus are of medium risk.

In Greece, according to van der Knijff et al. [88], who applied the USLE model in Europe, the annual soil loss generally fluctuates between 0 and $20 \mathrm{t} / \mathrm{ha}$. The largest part of northern and northwestern Greece and the far northwestern part of the Peloponnese are characterized by a low annual soil loss (generally less than $1 \mathrm{t} / \mathrm{ha}$ ). An exception would be the Strymonas basin, Chalkidiki and Olympus, where annual soil loss reaches, or possibly exceeds, $10 \mathrm{t} / \mathrm{ha}$ [90]. Central Greece, the Peloponnese and the Ionian islands are characterized by the highest soil rate, which is less than $5 \mathrm{t} / \mathrm{ha} /$ year in only a few areas. Most of these areas undergo a soil loss of 5 to $10 \mathrm{t} / \mathrm{ha}$ /year. Higher rates (10-20 t/ha/year) are mainly found in the northern Peloponnese.

Soil erosion, as well as other natural disasters (e.g., landslides, floods) are in most cases hindered or reduced when vegetation is abundant. Plants intercept the falling water through their leaves. In this way, water during a rainfall has a decreased velocity, i.e., a lower erodibility, whereas plants also absorb soil water through their roots, meaning that the soil becomes less saturated, and more water can infiltrate into the soil; hence, the surface runoff is significantly reduced [93-96]. Moreover, plants restrain soil particles, thus hindering them from being removed; they also create holes in the soil through their roots, further enabling water infiltration. Furthermore, a strong presence of plants means that soil roughness is increased, both directly (through the plants themselves) and indirectly (through dead leaves, trunks, etc.). In this way, soil particles are prevented from being transported downstream [93-96]. It is clear that in most cases, surface runoff erosion, especially when it comes to soils, is highly increased after a conflagration, as a massive amount of vegetation is usually rapidly dismantled.

The areas studied in this paper have undergone a significant vegetation loss due to the devastating fires of summer 2021. Therefore, surface runoff erosion was expected to be higher in the burnt areas than the areas that remained unaffected. In addition, the morphological slope of the study areas clearly affects the distribution of runoff erosion hazard. The results of the geomorphological and erosion-risk mapping have confirmed this expectation. All the burnt parts of the 10 individual areas that were severely affected by the forest fires, which were studied in this research (Vilia, Sounion, Varympompi, Northern Euboea, Aigialeia, Diavolitsi, Ancient Olympia, and Eastern Mani) are characterized by an increased susceptibility to erosion than their surrounding regions, despite the fact that, for each of these areas, the geomorphological and geological structure of the burnt and the non-burnt parts are similar. 


\section{Conclusions}

Vegetation plays a very important role in reducing surface runoff and hindering erosion, especially as far as soils are concerned. Areas affected by wildfires are more susceptible to surface runoff erosion, particularly when the fire event is very recent, and the dismantled vegetation has not regenerated. The more intense the conflagrations and/or the larger the area affected, the higher the erosion risk. The wildfires of summer 2021 were among the most devastating conflagration events that have struck Greece during recent decades, not only regarding duration and area, but also intensity. Therefore, surface runoff erosion risk is very high in the burnt areas. Our research has shown that all the burnt parts of the studied areas (Vilia, Sounion and Varympompi in Attica, Northern Euboea, Diavolitsi, Ancient Olympia, Aigialeia and Eastern Mani in the Peloponnese) are more susceptible to near-future erosion events than their surrounding non-burnt areas.

Supplementary Materials: The following are available online at https:/ / www.mdpi.com/article / 10.3390/land11010021/s1, Table S1: The Boolean logical rules used to derive the erosion risk.

Author Contributions: Conceptualization, N.E.; methodology, N.E.; validation, M.T., T.G.; investigation, N.E., M.T., T.G., E.S., G.S., A.P. and A.K.; writing-original draft preparation, N.E., M.T., E.S., G.S., A.P. and A.K.; writing-review and editing, N.E., M.T., G.S., A.P. and A.K.; supervision, N.E. All authors have read and agreed to the published version of the manuscript.

Funding: This research was funded by SARG-NKUA (Special Account for Research-National and Kapodistrian University of Athens).

Institutional Review Board Statement: Not applicable.

Informed Consent Statement: Not applicable.

Acknowledgments: The authors would like to thank three anonymous reviewers whose constructive comments and suggestions improved an earlier version of this paper.

Conflicts of Interest: The authors declare no conflict of interest.

\section{References}

1. Lekkas, E.; Parcharidis, I.; Arianoutsou, M.; Lozios, S.; Mavroulis, S.; Spyrou, N.-I.; Antoniou, V.; Nastos, P.; Mavrouli, M.; Speis, P.; et al. The July-August 2021 Wildfires in Greece. Newsl. Environ. Disaster Cris. Manag. Strateg. 2021, 25.

2. Charlton, R. Fundamentals of Fluvial Geomorphology; Routledge: London, UK, 2007; pp. 1-234. [CrossRef]

3. Huggett, R.J. Fundamentals of Geomorphology, 3rd ed.; Routledge: London, UK; New York, NY, USA, 2011.

4. Evelpidou, N. Geomorphology. Laboratory Exercises; Academic Press I. Basdras \& Co.: Alexandroupolis, Greece, 2018.

5. King, D.; Fox, D.M.; Daroussin, J.; Le Bissonnais, Y.; Danneels, V. Upscaling a simple erosion model from small areas to a large region. Nutr. Cycl. Agroecosyst. 1998, 50, 143-149. [CrossRef]

6. Van Der Knijff, J.M.; Jones, R.J.A.; Montanarella, L. Soil Erosion Risk Assessment in Italy; European Soil Bureau: Brussels, Belgium, 1999.

7. Grimm, M.; Jones, R.J.A.; Rusco, E.; Montanarella, L. Soil Erosion Risk in Italy: A Revised USLE Approach; European Commission Joint Research Centre: Ispra, Italy, 2003.

8. Kirkby, M.J.; Jones, R.J.A.; Irvine, B.; Gobin, A.; Govers, G.; Cerdan, O.; Van Rompaey, A.J.; Le Bissonnais, Y.; Daroussin, J.; King, D.; et al. Pan-European Soil Erosion Risk Assessment for Europe: The PESERA map, Version 1 October 2003. Explanation of Special Publication Ispra 2004 No. 73 (SPI); Office for Official Publications of the European Communities: Luxembourg, 2004.

9. Henin, S.; Gobillot, T. L'érosion en France. Bull. d'informations Tech. 1950, 50, 431-433.

10. Auzet, A. L'érosion des sols cultivés en France sous l'action du ruissellement. Ann. Georgr. 1987, 537, 529-556. [CrossRef]

11. Roering, J.J.; Mackey, B.H.; Marshall, J.A.; Sweeney, K.E.; Deligne, N.I.; Booth, A.M.; Handwerger, A.L.; Cerovski-Darriau, C. 'You are HERE': Connecting the dots with airborne lidar for geomorphic fieldwork. Geomorphology 2013, 200, 172-183. [CrossRef]

12. Tarolli, P. High-resolution topography for understanding Earth surface processes: Opportunities and challenges. Geomorphology 2014, 216, 295-312. [CrossRef]

13. Passalacqua, P.; Belmont, P.; Staley, D.M.; Simley, J.D.; Arrowsmith, J.R.; Bode, C.A.; Crosby, C.; DeLong, S.B.; Glenn, N.F.; Kelly, S.A.; et al. Analyzing high resolution topography for advancing the understanding of mass and energy transfer through landscapes: A review. Earth-Sci. Rev. 2015, 148, 174-193. [CrossRef]

14. Ardizzone, F.; Cardinali, M.; Galli, M.; Guzzetti, F.; Reichenbach, P. Identification and mapping of recent rainfall-induced landslides using elevation data collected by airborne Lidar. Nat. Hazards Earth Syst. Sci. 2007, 7, 637-650. [CrossRef] 
15. Jaboyedoff, M.; Oppikofer, T.; Abellán, A.; Derron, M.-H.; Loye, A.; Metzger, R.; Pedrazzini, A. Use of LIDAR in landslide investigations: A review. Nat. Hazards 2012, 61, 5-28. [CrossRef]

16. Pirotti, F. Laser Scanner Applications in Forest and Environmental Sciences. Ital. J. Remote Sens. 2012, 44, 109-123. [CrossRef]

17. Trevisani, S.; Cavalli, M.; Marchi, L. Surface texture analysis of a high-resolution DTM: Interpreting an alpine basin. Geomorphology 2012, 161-162, 26-39. [CrossRef]

18. Cavalli, M.; Trevisani, S.; Comiti, F.; Marchi, L. Geomorphometric assessment of spatial sediment connectivity in small Alpine catchments. Geomorphology 2013, 188, 31-41. [CrossRef]

19. Passalacqua, P.; Hillier, J.; Tarolli, P. Innovative analysis and use of high-resolution DTMs for quantitative interrogation of Earth-surface processes. Earth Surf. Process. Landf. 2014, 39, 1400-1403. [CrossRef]

20. Smith, M.W.; Vericat, D. From experimental plots to experimental landscapes: Topography, erosion and deposition in sub-humid badlands from Structure-from-Motion photogrammetry. Earth Surf. Process. Landf. 2015, 40, 1656-1671. [CrossRef]

21. Wischmeier, W.; Smith, D. Predicting Rainfall Erosion Losses: A Guide for Conservation Planning; USDA: Beltsville, MD, USA, 1978.

22. Desmet, P.J.J.; Govers, G. A GIS procedure for automatically calculating the USLE LS factor on topographically complex landscape units. J. Soil Water Conserv. 1996, 51, 427-433.

23. Renard, K.G.; United States. Agricultural Research Service. Predicting Soil Erosion by Water: A Guide to Conservation Planning with the revised Universal Soil Loss Equation (RUSLE); US Department of Agriculture, Agricultural Research Service: Washington DC, USA, 1997; ISBN 0160489385.

24. Angima, S.D.; Stott, D.E.; O'Neill, M.K.; Ong, C.K.; Weesies, G.A. Soil erosion prediction using RUSLE for central Kenyan highland conditions. Agric. Ecosyst. Environ. 2003, 97, 295-308. [CrossRef]

25. Renard, K.G.; Foster, G.R. Soil Conservation: Principles of Erosion by Water. Dryl. Agric./Ed. H.E. Dregne W.O. Willis. 1983. Available online: https:/ /agris.fao.org/agris-search/search.do?recordID=US201301916151 (accessed on 14 December 2021).

26. Kirkby, M.J.; Cox, N.J. A climatic index for soil erosion potential (CSEP) including seasonal and vegetation factors. CATENA 1995, 25, 333-352. [CrossRef]

27. Kirkby, M.J.; Bissonais, Y.L.; Coulthard, T.J.; Daroussin, J.; McMahon, M.D. The development of land quality indicators for soil degradation by water erosion. Agric. Ecosyst. Environ. 2000, 81, 125-135. [CrossRef]

28. Burrough, P.A. Fuzzy mathematical methods for soil survey and land evaluation. J. Soil Sci. 1989, 40, 477-492. [CrossRef]

29. Burrough, P.A.; Macmillan, R.A.; van Deursen, W. Fuzzy classification methods for determining land suitability from soil profile observations and topography. J. Soil Sci. 1992, 43, 193-210. [CrossRef]

30. Evelpidou, N.; Gournellos, T.; Karkani, A.; Kardara, E. Developing a neuro-fuzzy system to classify drainage sub-basins according to erosion processes on the Island of Lefkas, Greece. Rev. Geomorfol. 2018, 20, 79-89. [CrossRef]

31. Binaghi, E.; Luzi, L.; Madella, P.; Pergalani, F.; Rampini, A. Slope Instability Zonation: A Comparison Between Certainty Factor and Fuzzy Dempster-Shafer Approaches. Nat. Hazards 1998, 17, 77-97. [CrossRef]

32. Sabot, V.; Gournelos, T.; Evelpidou, N.; Vassilopoulos, A. Data base and erosion risk map creation at Trichonida lake using fuzzy sets and gis. Bull. Geol. Soc. Greece 2001, 34, 443-450.

33. Bartkowiak, A.; Gournellos, T.; Evelpidou, N.; Vassilopoulos, A. Self-organizing maps-a helpful tool in clustering areas with similar factors of erosion risk. In Proceedings of the 6th Pan-Hellenic Geographical Congress of the Hellenic Geographical Society, Thessaloniki, Greece, 3-6 October 2002; pp. 87-94.

34. Evelpidou, N.; Gournellos, T.; Kardara, E.; Karkani, A. Fuzzy modelling of slope erosion by runoff. Case study in Corinth basin, Greece. Rev. Geomorfol. 2018, 20, 34-42. [CrossRef]

35. Yesilnacar, E.; Topal, T. Landslide susceptibility mapping: A comparison of logistic regression and neural networks methods in a medium scale study, Hendek region (Turkey). Eng. Geol. 2005, 79, 251-266. [CrossRef]

36. Melchiorre, C.; Matteucci, M.; Azzoni, A.; Zanchi, A. Artificial neural networks and cluster analysis in landslide susceptibility zonation. Geomorphology 2008, 94, 379-400. [CrossRef]

37. De la Rosa, D.; Moreno, J.A.; Mayol, F.; Bonsón, T. Assessment of soil erosion vulnerability in western Europe and potential impact on crop productivity due to loss of soil depth using the ImpelERO model. Agric. Ecosyst. Environ. 2000, 81, 179-190. [CrossRef]

38. Behrens, T.; Förster, H.; Scholten, T.; Steinrücken, U.; Spies, E.D.; Goldschmitt, M. Digital soil mapping using artificial neural networks. J. Plant Nutr. Soil Sci. 2005, 168, 21-33. [CrossRef]

39. Gournellos, T.; Evelpidou, N.; Karkani, A.; Kardara, E. Recognition of erosion risk areas using Neural Network Technology: An application to the Island of Corfu. Rev. Geomorfol. 2018, 20, 56-65. [CrossRef]

40. Cremers, N.H.D.; Van Dijk, P.; De Roo, P.; Verzandvoort, M. Spatial and temporal variability of soil surface roughness and the application in hydrological and soil erosion modelling. Wiley Online Libr. 1996, 10, 1035-1047. [CrossRef]

41. Smith, R.E.; Goodrich, D.C.; Unkrich, C.L. Simulation of selected events on the Catsop catchment by KINEROS2 A report for the GCTE conference on catchment scale erosion models. Catena 1999, 37, 457-475. [CrossRef]

42. Hessel, R.; Jetten, V.; Guanghui, Z. Estimating Manning's n for steep slopes. Catena 2003, 54, 77-91. [CrossRef]

43. Moffet, C.A.; Pierson, F.B.; Robichaud, P.R.; Spaeth, K.E.; Hardegree, S.P. Modeling soil erosion on steep sagebrush rangeland before and after prescribed fire. Catena 2007, 71, 218-228. [CrossRef]

44. Mügler, C.; Planchon, O.; Patin, J.; Weill, S.; Silvera, N.; Richard, P.; Mouche, E. Comparison of roughness models to simulate overland flow and tracer transport experiments under simulated rainfall at plot scale. J. Hydrol. 2011, 402, 25-40. [CrossRef] 
45. Gilley, J.E.; Finkner, S.C. Hydraulic roughness coefhcients as affected by random roughness. Trans. ASAE 1991, 34, 897-903. [CrossRef]

46. Mwendera, E.J.; Feyen, J. Estimation of depression storage and Manning's resistance coefficient from random roughness measurements. Geoderma 1992, 52, 235-250. [CrossRef]

47. Zobeck, T.M.; Onstad, C.A. Tillage and rainfall effects on random roughness: A review. Soil Tillage Res. 1987, 9, 1-20. [CrossRef]

48. Reaney, S.M.; Bracken, L.J.; Kirkby, M.J. The importance of surface controls on overland flow connectivity in semi-arid environments: Results from a numerical experimental approach. Hydrol. Process. 2014, 28, 2116-2128. [CrossRef]

49. Zheng, Z.C.; He, S.Q.; Wu, F.Q. Relationship between soil surface roughness and hydraulic roughness coefficient on sloping farmland. Water Sci. Eng. 2012, 5, 191-201. [CrossRef]

50. Yan, T.; Wang, Z.; Liao, C.; Xu, W.; Wan, L. Effects of the morphological characteristics of plants on rainfall interception and kinetic energy. J. Hydrol. 2021, 592, 125807. [CrossRef]

51. Brown, L. Conserving soils. In State of the World; Scientific Publishers: Rajasthan, India, 1984; Volume 53, pp. 53-75.

52. Antoneli, V.; Rebinski, E.; Bednarz, J.; Rodrigo-Comino, J.; Keesstra, S.; Cerdà, A.; Pulido Fernández, M. Soil Erosion Induced by the Introduction of New Pasture Species in a Faxinal Farm of Southern Brazil. Geosciences 2018, 8, 166. [CrossRef]

53. Klik, A. Einfluss unterschiedlicher bodenbearbeitung auf oberflachenabfluss, bodenabtrag sowie auf nahrst- off- und pestizidaustrage. Osterr. Wasser-und Abfallwirtsch. 2003, 55, 89-96.

54. Komissarov, M.A.; Klik, A. The Impact of No-Till, Conservation, and Conventional Tillage Systems on Erosion and Soil Properties in Lower Austria. Eurasian Soil Sci. 2020, 53, 503-511. [CrossRef]

55. Shakesby, R.A.; Doerr, S.H.; Walsh, R.P.D. The erosional impact of soil hydrophobicity: Current problems and future research directions. J. Hydrol. 2000, 231-232, 178-191. [CrossRef]

56. Shakesby, R.A.; Wallbrink, P.J.; Doerr, S.H.; English, P.M.; Chafer, C.J.; Humphreys, G.S.; Blake, W.H.; Tomkins, K.M. Distinctiveness of wildfire effects on soil erosion in south-east Australian eucalypt forests assessed in a global context. For. Ecol. Manag. 2007, 238, 347-364. [CrossRef]

57. Wondzell, S.M.; King, J.G. Postfire erosional processes in the Pacific Northwest and Rocky Mountain regions. For. Ecol. Manag. 2003, 178, 75-87. [CrossRef]

58. Certini, G. Effects of fire on properties of forest soils: A review. Oecologia 2005, 143, 1-10. [CrossRef]

59. Shakesby, R.A.; Doerr, S.H. Wildfire as a hydrological and geomorphological agent. Earth-Sci. Rev. 2006, 74, 269-307. [CrossRef]

60. Pérez-Cabello, F.; Cerdà, A.; de la Riva, J.; Echeverría, M.T.; García-Martín, A.; Ibarra, P.; Lasanta, T.; Montorio, R.; Palacios, V. Micro-scale post-fire surface cover changes monitored using high spatial resolution photography in a semiarid environment: A useful tool in the study of post-fire soil erosion processes. J. Arid Environ. 2012, 76, 88-96. [CrossRef]

61. Shakesby, R.A.; Bento, C.P.M.; Ferreira, C.S.S.; Ferreira, A.J.D.; Stoof, C.R.; Urbanek, E.; Walsh, R.P.D. Impacts of prescribed fire on soil loss and soil quality: An assessment based on an experimentally-burned catchment in central Portugal. Catena 2015, 128, 278-293. [CrossRef]

62. Kutiel, P.; Inbar, M. Fire impacts on soil nutrients and soil erosion in a Mediterranean pine forest plantation. Catena 1993, 20, 129-139. [CrossRef]

63. Kutiel, P.; Lavee, H.; Segev, M.; Benyamini, Y. The effect of fire-induced surface heterogeneity on rainfall-runoff-erosion relationships in an eastern Mediterranean ecosystem, Israel. Catena 1995, 25, 77-87. [CrossRef]

64. Stoof, C.R.; Ferreira, A.J.D.; Mol, W.; Van den Berg, J.; De Kort, A.; Drooger, S.; Slingerland, E.C.; Mansholt, A.U.; Ferreira, C.S.S.; Ritsema, C.J. Soil surface changes increase runoff and erosion risk after a low-moderate severity fire. Geoderma 2015, 239-240, 58-67. [CrossRef]

65. Cannon, S.H.; Gartner, J.E.; Rupert, M.G.; Michael, J.A.; Rea, A.H.; Parrett, C. Predicting the probability and volume of postwildfire debris flows in the intermountain western United States. GSA Bull. 2010, 122, 127-144. [CrossRef]

66. Cerda, A.; Robichaud, P.R. Fire Effects on Soil Infiltration. In Fire Effects on Soils and Restoration Strategies; CRC Press: Boca Raton, FL, USA, 2009; pp. 97-120. [CrossRef]

67. Smith, H.G.; Sheridan, G.J.; Lane, P.N.J.; Nyman, P.; Haydon, S. Wildfire effects on water quality in forest catchments: A review with implications for water supply. J. Hydrol. 2011, 396, 170-192. [CrossRef]

68. Morales, H.A.; Návar, J.; Domínguez, P.A. The effect of prescribed burning on surface runoff in a pine forest stand of Chihuahua, Mexico. For. Ecol. Manag. 2000, 137, 199-207. [CrossRef]

69. Benavides-Solorio, J.; MacDonald, L.H. Post-fire runoff and erosion from simulated rainfall on small plots, Colorado Front Range. Hydrol. Process. 2001, 15, 2931-2952. [CrossRef]

70. Cootei, D.; Malcolm-mcgo, C.; Wall, G.; Dickinsons, W.; Ano, W. Seasonal variation of erodibility indices based on shear strength and aggregate stability in some Ontario soils. Can. J. Soil Sci. 1988, 68. [CrossRef]

71. Martin, D.A.; Moody, J.A. Comparison of soil infiltration rates in burned and unburned mountainous watersheds. Hydrol. Process. 2001, 15, 2893-2903. [CrossRef]

72. Alauzis, M.V.; Mazzarino, M.J.; Raffaele, E.; Roselli, L. Wildfires in NW Patagonia: Long-term effects on a Nothofagus forest soil. For. Ecol. Manag. 2004, 192, 131-142. [CrossRef]

73. García-Corona, R.; Benito, E.; de Blas, E.; Varela, M.E.; García-Corona, R.; Benito, E.; de Blas, E.; Varela, M.E. Effects of heating on some soil physical properties related to its hydrological behaviour in two north-western Spanish soils. Int. J. Wildl. Fire 2004, 13, 195-199. [CrossRef] 
74. Keeley, J.E. Fire intensity, fire severity and burn severity: A brief review and suggested usage. Int. J. Wildl. Fire 2009, 18, 116-126. [CrossRef]

75. Stoof, C.R.; Vervoort, R.W.; Iwema, J.; VanDenElsen, E.; Ferreira, A.J.D.; Ritsema, C.J. Hydrological response of a small catchment burned by experimental fire. Hydrol. Earth Syst. Sci. 2012, 16, 267-285. [CrossRef]

76. Mataix-Solera, J.; Cerdà, A.; Arcenegui, V.; Jordán, A.; Zavala, L.M. Fire effects on soil aggregation: A review. Earth-Sci. Rev. 2011 109, 44-60. [CrossRef]

77. Aznar, J.M.; González-Pérez, J.A.; Badía, D.; Martí, C. At What Depth Are The Properties of a Gypseous Forest Topsoil Affected By Burning? Land Degrad. Dev. 2016, 27, 1344-1353. [CrossRef]

78. Wells, C.; Campbell, R.; Debano, L.; Lewis, C.; Predriksen, R.; Franklin, E.; Froelich, R.; Dunn, P. Effects of Fire on Soil: A State of Knowledge Review; General Technical Report WO-7; U.S. Department of Agriculture, Forest Service: Washington, DC, USA, 1979.

79. Fernández, C.; Vega, J.A.; Jiménez, E.; Vieira, D.C.S.; Merino, A.; Ferreiro, A.; Fonturbel, T. Seeding and mulching + seeding effects on post-fire runoff, soil erosion and species diversity in Galicia (NW Spain). Land Degrad. Dev. 2012, 23, 150-156. [CrossRef]

80. Prats, S.A.; MacDonald, L.H.; Monteiro, M.; Ferreira, A.J.D.; Coelho, C.O.A.; Keizer, J.J. Effectiveness of forest residue mulching in reducing post-fire runoff and erosion in a pine and a eucalypt plantation in north-central Portugal. Geoderma 2012, 191, 115-124. [CrossRef]

81. Pereira, P.; Francos, M.; Brevik, E.C.; Ubeda, X.; Bogunovic, I. Post-fire soil management. Curr. Opin. Environ. Sci. Health 2018, 5 , 26-32. [CrossRef]

82. Hellenic National Meteorological Service. Available online: http:/ / www.emy.gr/emy/el/climatology/climatology_city (accessed on 16 December 2021).

83. EEA Corine Land Cover (CLC) 2018. Available online: https://land.copernicus.eu/pan-european/corine-land-cover/clc2018 (accessed on 14 November 2021).

84. Gawthorpe, R.L.; Leeder, M.R.; Kranis, H.; Skourtsos, E.; Andrews, J.E.; Henstra, G.A.; Mack, G.H.; Muravchik, M.; Turner, J.A.; Stamatakis, M. Tectono-sedimentary evolution of the Plio-Pleistocene Corinth rift, Greece. Basin Res. 2018, 30, 448-479. [CrossRef]

85. Boardman, J.; Poesen, J. Soil Erosion in Europe. Available online: https://books.google.gr/books?hl=el\&lr=\&id= vvOFRskFunwC\&oi=fnd\&pg=PR7\&dq=Soil+Erosion+in+Europe\&ots=ipm-ALPCXM\&sig=Gc43BQVyZxzFN1JbNQlbWEcDm3 8\&redir_esc $=\mathrm{y} \# \mathrm{v}=$ onepage $\& \mathrm{q}=$ SoilErosioninEurope $\& \mathrm{f}=$ false (accessed on 20 November 2021).

86. Kepner, W.; Rubio, J.; Mouat, D.; Pedrazzini, F. Desertification in the Mediterranean Region. A Security Issue. In Proceedings of the NATO Mediterranean Dialogue Workshop, Valencia, Spain, 2-5 December 2006.

87. Grove, A.; Rackham, O. The Nature of Mediterranean Europe: An Ecological History; Yale University Press: New Haven, CT, USA, 2003

88. van der Knijff, J.M.; Jones, R.J.A.; Montanarella, L. Soil Erosion Risk Assessment in Europe; Office for Official Publications of the European Communities: Luxembourg, 2000.

89. Blondel, J. The "design" of Mediterranean landscapes: A millennial story of humans and ecological systems during the historic period. Hum. Ecol. 2006, 34, 713-729. [CrossRef]

90. Lasanta, T.; Nadal-Romero, E.; Errea, M.P. The footprint of marginal agriculture in the Mediterranean mountain landscape: An analysis of the Central Spanish Pyrenees. Sci. Total Environ. 2017, 599-600, 1823-1836. [CrossRef] [PubMed]

91. CORINE. Soil Erosion Risk and Important Land Resources in the Southern Regions of the European Community; European Environment Agency: Luxembourg, 1992.

92. RIVM. The Environment in Europe: A global Perspective; RIVM: Bilthoven, The Netherlands, 1992.

93. Wilson, E. Engineering Hydrology, 4th ed.; MacMillan Press Ltd.: London, UK, 1990.

94. Smith, K.; Ward, R. Floods: Physical Processes and Human Impacts; Wiley: Hoboken, NJ, USA, 1998; ISBN 978-0-471-95248-0.

95. Ward, R.; Robinson, M. Principles of Hydrology, 4th ed.; McGraw-Hill: London, UK, 2000.

96. Diakakis, M. Flood Hazard Assessment with the Use of Modeling Techniques; National and Kapodistrian University of Athens: Athens, Greece, 2012. 